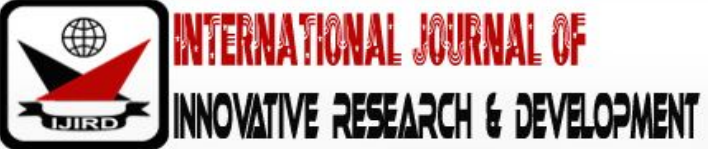

ISSN 2278 - 0211 (Online)

\section{Technology Transfer: Role of FDI and Trade Case of Tunisia}

\author{
Fatma Abdelkaoui \\ Ph.D. Student, Department of Economics, I.H.E.C Carthage, Tunisia \\ Mariem Bouzidi \\ Ph.D. Student, Department of Economics, I.H.E.C Carthage, Tunisia
}

\begin{abstract}
:
The aim of this study is to analyze by which means Tunisia transfers to her area the technology is it through foreign investment or international trade? The answers to this problem was gradual as we followed an approach using economic theory, the reality of Tunisia and econometric and statistical tools. We tested the relation between Technology transfers and the Foreign investment, trade in Tunisia over a period of 38 years from 1975 to 2013.So, we estimated in two phases, for the $1^{\text {ST }}$ estimation is for the economic growth equation, and we deduced that residue is a proxy of technology. Then as a second phase, we regressed on European Foreign investment, exports of manufactures, imports of goods in addition to other variable to test the robustness of the results and describing the level of infrastructure in the country.

Thus, it appears from our study that foreign direct investment does not contribute in transferring the technology and does not have an impact on the economic growth of Tunisia. However, it follows from our study that the international trade only through the imports represent the main channel of technology transfer in Tunisia
\end{abstract}

Keywords: Technology transfer, foreign direct investment, trade, economic growth

\section{Introduction}

Many countries whether industrialized or newly industrialized countries such as china, South Korea, Mexico and Brazil considerate as a successful example of technological transfer. Those countries have succeeded to transfer to her area a sophisticated and developed technology.

This transfer allowed to those countries not only to boost them productivity factors and ameliorate the rate of them economic growth but also to profit from the spillovers of this transfer such as a strong competition and offers for them the ability to ameliorate them openness degree and a higher development level.

However, for Tunisia case, because of the failure of the socialization experience of its economy during the 60 "s, the governments have applied a radical change occurred to her economic policy in the early 70s. This change based on encouraging the development of export industries; ameliorate the partnership system, improve the number of foreign firms in Tunisia. One of the basic objectives that Tunisian government has fixed to with the new strategy of the 70"s is the ability to own sophisticate, high level technologies to profit from it like the other developed countries specially when this technology became a curtails instruments of developing and a factor to raise the rate of the economic growth.

Therefore, technology has become a necessity to Tunisia for several reasons such as:

- Catch up the developed countries

- Ameliorate and developed her productivity factors

- Boost her competition capacity and the ability to face some strong competitors

- Protect her local market form foreign domination

- Ability to create new jobs, so decreasing the unemployment rate

Thus, according to many studies this objective of technology transfer can be reached only through 2 essential channels, first the Foreign direct investment and second the international trade, and those channels for Tunisia are the basic pillars of her economy. So, the curtail questions that should be answered to analyses whether the objects have been reached or not are: What is the real contribution of foreign investments and the international Trade in Tunisian economy? And which one of those channels does truly transfer technology to it?

\section{Review of the Empirical Literature}

Most of empirical literature is trying to prove that one of those instrument FDI and international trade are not only one of basic pillars of the fulcrum for the economic development of the countries but also one of the main channel of technology transfer Therefore we can note that all of those studies try to reach one of those result and conclusion: 
FDI leads to economic growth, so have a positive impact on the economy and also transferring technology to those host countries, also FDI can contribute to economic growth of developing countries that if they have minimum stock of human capital that enable to use the benefit from technology diffused:

- Famous Empirical studies that support this conclusion: Blomstrom and Al 1998 and DE Mello 1999, They found that the effect of FDI is more important for developing countries only if those FDIs is with high income.

- Empirical studies that support this conclusion: Borenztein and al 1998 , Xu 2000, Lee 2001 : they found developing countries a minimum share of human capital is required to benefits from FDI more account way to benefit from foreign technologies and the majority of developing countries have not reached yet that threshold

The presence of sufficient degree of openness in the host country that may help to boost the international trade contribution in those countries that seeking for economic growth and which considerate by same authors as the key for a successful technology transfer and diffusion specially for development countries:

- same of famous empirical study that proves this result is the one of De Melle 1997 how concluded that Trade policies in the host countries appears to shows that there is link between trade regimes and economic growth that lead to technology transfer.

- other studies like Atikal and banga 2003 on India how proves that trade is the essential channel of technology transfer

With lesser interest few studies has analysis both instruments together to find out which one between both in the same model is the main channel of technology transfer and which one has better and bigger impact on the economic growth such as:

- Alaya in 2006 , study the impact of FDI and trade on Tunisia , morocco , turkey and she found out that FDI has negative impact on economic growth and the Economic growth in those countries is mainly determined by TRADE And local investment and lesser interest by human capital.

- Alaya2010 , find out that both instruments has a positive impact on the economic growth and both can be considerate as channels of technological transfer

\section{Model Specification}

The growth is the result of the increase in total output of an economy, as macroeconomic production function is the center of his analysis. Macroeconomic production function is a representation of the production activity at the aggregate level; this is a summary of all firms" production functions.

The functions of individual productions (those firms) are obviously the only ones having a real existence; the aggregate function can only be an analytical construction. Many discussions focused on the possibility of such a construction in the 60s in particular. We show easily, especially as macroeconomic production function can be achieved by simply adding individual features (the nature of the returns of individual functions is not stored). Macroeconomic production function, whatever its method of production, can only be an approximation, which must be sufficiently loyal, actual production conditions of the economy.

$\bar{Y}_{t}=F(K, L)$

$\mathrm{Y}=$ real national income (by volume)

$\mathrm{K}=$ the total capital stock

$\mathrm{L}=$ labor (labor force).

The model that used in the following empirical study has its dynamic in production function in neoclassical macroeconomic level (neoclassical production function Solow)as a Cobb-Douglas production function.

$Y=A K^{\alpha} L^{\beta}$

$\mathrm{K}=$ capital of capital used

- $\quad$ L=Quantity of labor used,

- $\quad A=$ is a Coefficient that characterize the dimension of the economy

[?] $\alpha+\beta=1$ so, the returns to scale are constant

0] 0 with $\alpha=$ Part of capital price and $\beta=$ Part of labor price

Based on Denin and carre also on Deboise and Malinvard franc which They found that is possible to calculate the economic growth even in the absence of population and later this has been confirmed by neoclassical theory. Indeed, with a CobbDouglas function of the form $Y=A K^{\alpha} L^{\beta}$ take the Differential $Y$.

$d Y=\frac{\partial Y}{\partial K} d K+\frac{\partial Y}{\partial L} d L$

$d y=\alpha K^{\alpha-1} L^{b} d K+\beta K^{\alpha} L^{\beta-1} d L$

$d y=\alpha Y \frac{d k}{k}+\beta Y \frac{d l}{l}$

If we divided the equation with $Y) \frac{d y}{y}=\alpha \frac{d k}{k}+\beta \frac{d l}{l}$

$\mathrm{g}=\alpha \mathrm{PMK}+\beta \mathrm{PML}$

$g=$ economic growth

PMK = the marginal productivity of capital

PML = marginal productivity of labor. 
Economic growth is equal to the sum of growth rates of capital and labor weighted by the share of profit and wages in total incomes. However, the economic growth equation has developed after 30's booms, several empirical papers has confirmed, the Neoclassical theorist, found that an important part of the economic growth called residual remain unknown only few they defined as technical progress (as Smith and BARRO).

Therefore, it necessary to introduce in the analysis a factor that explains the unknown part of the economic growth. According to empirical study, technical progress was conceived as a constant trend in time from a certain starting level. At time , Technical progress would be noted as " $\mathrm{H}$ " so it will be equal to

$\mathrm{Ht}=\mathrm{Hoe}^{\lambda \mathrm{t}}$

the production function will be:

$\mathrm{Yt}=\mathrm{HtKt^{ \alpha }} \mathrm{Lt}^{\beta}$

$\mathrm{Yt}=\mathrm{Hoe}^{\lambda t} \mathrm{Kt}^{\alpha} \mathrm{Lt}^{\beta}$

$\mathrm{dY}=\frac{\partial \mathrm{y}}{\partial \mathrm{t}} \mathrm{dt}+\frac{\partial \mathrm{y}}{\partial \mathrm{k}} \mathrm{dk}+\frac{\partial \mathrm{y}}{\partial \mathrm{L}} \mathrm{dL}$

$d Y=\lambda H 0 e^{\lambda t} K^{\alpha} L^{\beta}{ }^{\beta} d t+\alpha H 0 e^{\lambda t} K^{\alpha-1} L^{\beta} d K+\beta H 0 e^{\lambda t} K^{\alpha} L^{\beta}{ }^{\beta-1} d L$

If we divided all the equation by $\mathrm{Y}: \frac{\mathrm{dY}}{\mathrm{Y}}=\lambda \mathrm{dt}+\alpha \frac{\mathrm{dk}}{\mathrm{k}}+\beta \frac{\mathrm{dL}}{\mathrm{L}} \mathrm{So}$

We have a decomposition of economic growth showing the respective contributions to the growth of each factor to technical progress. following El Mouhoub.M and Jamal.J and Helam.H (2009) and Nassif Wahiba(2012), The economic growth can be measured by the rate of GDP and we can use as variable to explained but it depend on the availability of those variable :

- Rate GDP

- FDI : the ration Foreign invest to GDP

- HK : human capital : The enrollment rate at the secondary level

- DI ; the ratio Domestic invest to GDP

- $\mathrm{X}$ : The ratio of exports to GDP

- PL: The population growth rate

- $\mathrm{M}$ : The ratio of imports to GDP

- Et : error

So the 1 st equation of the model will be like

RGDP $=\mathrm{C}+\mathrm{a} 1 * \mathrm{FDI}+\mathrm{a} 2 * \mathrm{HK}+\mathrm{a} 3 * \mathrm{X}+\mathrm{a} 4 * \mathrm{DI}+\mathrm{a} 5 * \mathrm{PL}+\mathrm{a} 6 * \mathrm{~m}++\varepsilon t$

Once the estimation of Equation 1 is done, we try to recover the residue, representing a proxy for the technology we regress on the following variables

- Xma: part of manufactured export in the total exports

- Mma: The ratio of imports to GDP

- Tel : as proxy for infrastructure: number of phone line by 100/ resident

- $\quad$ FDI (7(UE) :the ration of Foreign invest to GDP of EU7

Specification in step 2 is as follows:

$\varepsilon \mathrm{t}=\mathrm{C}+\mathrm{a} 1 *$ Xma $+\mathrm{a} 2 *$ Mma $+\mathrm{a} 3 *$ tel $+\mathrm{a} 4 *$ FDI(7E.U) $+\varepsilon \mathrm{t}$

\section{Data}

The data used in this research are draw from 1975-2013. The statistics are collected from the World Bank database (WBI 2010) available on its website. These include the following series: The real Gross Domestic Product growth rate (\%),foreign direct Investment, Exports of goods and services (\% of GDP), Import of goods and services (\% of GDP), Fixed telephone subscriptions, Manufactures exports (\% of merchandise exports), manufactures Imports (\% of merchandise imports), Population growth (annual \%), the enrollment rate in secondary education (in \%), Domestic Investment.

To complete the statistical series, we appealed to the UNCTAD database. L'INS Tunisia, and the organization of economic co-operation and development, last and not least, statistical database of the European Union Eurostat to collect from it:The Foreign investment of basic 7 European countries in Tunisia such as French, Italy, Germany, Netherlands, Belgium, Luxembourg and Sweden

\section{Empirical Analysis}

Before reviewing the results of estimates it is imperative to examine the stationary of time series which will carry our regressions. Therefore, a statistical series called not stationery, if their variables are correlated presently. In other world, the value of each period depends heavily on its past or previous achievements, the variable whose auto-correlated is close to unity which is only decreasing slowly but remaining significantly different of zero to some orders, so, they are non-stationary variables.

Thereis one way to ensure the stationary, of time series by applying the unite root test of Augmented Dickey Filler (ADF). For this study we aregoing to apply the ADF test augmented Dickey-Fuller for the 3rd specification (constant and trend), as a result we deduced that some variables such as Gross domestic product, Foreign investment, domestic investment, population growth, imports, export and Foreign investment (7 euro) are stationary in 1 stdifference. However, the rest of the variables are stationary in $2^{\text {nd }}$ difference like the Exports of goods and services, import of goods and services, Fixed telephone subscriptions and the Foreign investment of basic 7 European the results are shown table 1 annexes I. 


\section{Results}

The first estimation of Equation 1 by using the OLS regression gives the results shown in Table5 2 below.

\begin{tabular}{|c|c|c|c|c|}
\hline Variable & Coefficient & Std.Error & T-Statistic & Prob \\
\hline C & -18.1119 & 8.892 .3816 & -2.02962 & 0.0536 \\
\hline FDI & -0.14755 & 0.262856 & -0.56132 & 0.5798 \\
\hline HK & 0.032326 & 0.040159 & 0.804941 & 0.4288 \\
\hline X & 1.024004 & 0.316262 & 3.237835 & 0.0035 \\
\hline DI & 0.965 & 0.272469 & 3.541681 & 0.0017 \\
\hline PL & -0.00963 & 1.009038 & -0.00954 & 0.9925 \\
\hline M & -1.02463 & 0.28949 & -3.53942 & 0.0017 \\
& & & & \\
\hline
\end{tabular}

Table 2: Estimation result

The previous result of the OLs regression cannotbe considered as a final result only if we verify the condition of this method:

- Heteroskedasticity. The variance of " $\varepsilon t$ " should be constant in time: we applied the breusch-pagan-godfrey test, as a result we find the p.value $=0.42>5 \%$, so the model is homoskedasticity so the var $(\varepsilon)$ is constant

- Autocorrelation: , it means that the covariance between $\varepsilon$ should be equal to 0 , we applied also the breuschgodfrey serial correlation $\mathrm{lm}$ test as a result we find the p.value $=0.9922>5 \%$, so absence of autocorrelation issue therefore $\operatorname{cov}(\varepsilon t, \varepsilon s)=0$

So, we can take the pervious regression as a final one because she verifies all the condition of the OLS.

The residue resulting from the previous result estimation is illustrated in Annex II. (Fig 1). The residue retained estimation in $1^{\text {st }}$ phases is used in the regression of the $2^{\text {nd }}$ equation above as a proxy for technology.

The estimation of equation 2 gives us the following result ${ }^{1}$

$\varepsilon t=-15,366+2.8335$ FDI (euro7) $+0.244750 M m a-0.028166 X m a-0.139865$ TEL

$(-2.8744)(2.0317)(2.52925)(-0.5687)(-0.97805)$

It thus, in $1 \%$ level it appears from the estimation that neither Foreign investment nor the infrastructure and the export is significant, only importing new equipment has a significant positive effect, these results confirm the theory that trade - via imports are-channel transmission technology. Such as the work of Coe and Helpman (1995); Coe, Helpman and Hoffmaister (1997); Enenson (1995); Keller (1997) and Jamal B., H. Hicham El Mouhoub M. (2009) and Nassifwahiba (2012)

International trade as imports is seen as an instrument of dissemination of technology. Tunisia, like all developing countries, unable to produce knowledge as some authors defined as technology, must resort to foreign imports and operate as a source of accumulation of technology.

Our study shows that FDI do not transfer technology and do not as well have a positive impact on growth. It seems for the Tunisian case, that the nature of foreign investment does not help enough or at all in transferring the technology and that may be because the latter is concentrated in sectors with low technological contributions such as textiles and do not boost the economic growth as well.

\section{Discussion and Conclusions}

We have seen in this study; the same empirical studies agree with the fact that FDI is the main channel of the technology transfer but also we view too that other studies parallel considered that international trade via imports promotes the transfer of the technology. The degree, the direction and magnitude of this transfer changes from one country to another and from one region to another

Overall, it seems that despite the different conclusion between the empirical studies, some of them conclude and conformed that there is a positive and significant effect of trade liberalization via imports on technology and it help countries specially the development ones to transfer developed and sophisticated technologies, this effect can have reached to insure the productivity gains and the growth of production (Cogneau, Dumont, and Mouhoud [2000]). However, the availability and the efficiency of skilled labor, which is a mean of the productivity and economic growth, appears as a strong condition for the effectiveness of this liberalization. In the case that we studied which is the case of Tunisia and the purpose of our estimation we realized that FDI does not contribute to technology transfers and do not affects the economic growth of it and the international trade not only affect the economic growth positively through import and negatively via export but also that only imported capital good appears to be the main channel of technology transfer in Tunisia.

This result forces us to ask a series of questions such as the effectiveness of the strategy of Tunisia to attract the FDI with high technology elements and the nature of the incentives granted by the State to foreign investors to push and encourage them to choose Tunisia as a destination to invest. However, it is true that Imports are channels to transfer 
technology to the country but the question is, it's enough to guaranty a sophisticate technology? and whether those technologies transferred are they developed enough to enhance the industrial sectors of Tunisia?

\section{References}

i. Ali .t.sadik and ali.a.balbol (2001), "capital flows, fdi and technology spillovers, evidence from arab countries", world development .vol29.no12.pp.2011-2125

ii. Bouoiyour jamal, mouhoud el mouhoub and hanchane hicham 2008 "investissements directs étrangers et croissance économique : estimation d"un modèle à erreurs composées » mpra paper no. 29152, posted 26

iii. Centre for european policy studies (ceps), brussels (project coordinator) korean institute for international and economic policy (kiep), seoul 2007 "a qualitative

iv. Changhai wang, yali wen *, feng han 2012, "study on china"s outward fdi" procedia environmental sciences no 12 pp $543-549$

v. Colin a.carter and alper yilmaz 1999 "fdi and trade : substitutes or complements" aaea annual meeting , nashville tn

vi. Dr. Keith maskus , dr. Kamal saggi 2014 , "international technology transfer: an analysis from the perspective from developing countries" cdip/ 14/inf/ 11

vii. E. Borenszteina , j. De gregorio, j-w. Lee (1998) "how does foreign direct investment affect economic growth?" Journal of international economics no 45 pp. 115-135

viii. Elifbascavusoglu 2015 "does international trade transfer technology to emerging countries? A patent citation analysis" faculty of social sciences working paper no 14

ix. Evissinani ,kaus.e.meyer 2004 "spillover of technology transfer for fdi :the case of estonia" journal of comperative economics no32 pp445-446

x. Francoise lemoine and deniz unal kesenci 2004 "assembly trade and technology transfer: the case of china" world development vol. 32, no. 5, pp. 829850.

xi. Ghazouani assaad and teraoui hedia 2014 "technology transfer and fdi: some lessons for tunisia" asian economic and financial review, n4(vol1) pp 90-104

xii. Giuditta de prato and daniel nepelski 2013 "international technology transfer between china and the rest of the world" institute for prospective technological studies

xiii. Guillaume gaulier, francoise lemoine and denizunal-kesenci2007, "china"s integration in east asia:production sharing, fdi \& high-tech trade" econ change, no40 pp 27-63

xiv. Hadhek zouhaier1 \&mrad fatma 2014 "foreign direct investment, intellectual property rights and economic growth: a panel study for arabic countries" international journal of economics and finance; vol. 6, no. 5 pp. 19169728

xv. Holger görg and david greenaway 2003 "do domestic firms really benefit from foreign direct investment?” Iza discussion paper no. 944

xvi. Holger görg and eric strobl 2003 "multinational companies, technology spillovers, and plant survival" diw berlin german institute for economic research , discussion papers $n, 366$

xvii. Imendaoudnaanaa and fethisellaouti 2013 "the role of foreign presence in the technology transfer" international journal of trade, economics and finance, vol. 4, no. 6

xviii. Investing across borders 2010 : "indicators of foreign direct investment regulation in 87 economies" made it by ifc, the world bank and world bank group

xix. Jamal bouoiyour, hicham hanchane and el mouhoubmouhoud, 2009 "investissements directs étrangers et productivité quelles interactions dans le cas des pays du moyen orient et d"afrique du nord ? » revue économique - vol. 60, n 1, p. 109-132

xx. Joëltoujas-bernaté, boileauloko, and dominique simard 2009 « tunisia selected issues: investigating growth spillovers from europe" imf country report no. 10/ 109

xxi. June-dong kim, sang-in hwang 2000 "the role of foreign direct investment in korean economic development: productivity effects and implications for the currency crisis" university of chicago press (p. 267 - 294)

xxii. Khalid sekkat and marie-ange véganzonès-varoudakis 2004 "trade and foreign exchange liberalization, investment climate, and fdi in the mena countries" cerdi, etudes et documents, e 2004.30

xxiii. Koji miyamoto 2013 , "human capital formation and foreign direct investment in developing countries", oecd development centre, working paper no. 211

xxiv. Magnus blomström\& ari kokko 2003 "the economics of foreign direct investment incentives" stockholm school of economics working paper 168

xxv. Magnus blomstrom, frederick sjoholm 1998, "technology transfer and spillovers: does local participation with multinationals matter", european economics reviews.no43.pp915-925

xxvi. Margret abiola loto1 taiwo victor ojapinwa 2014 "capital formation, technological diffusion and economic growth in nigeria: an ardl bound testing analysis" journal of economics and sustainable development, vol5 no19 pp. 2222-2855

xxvii. Maria paula frontoura2007, "determent factors of fdi spillover :what do we really know?”, world development.vol35.no3.pp410-425

xxviii. Mary amiti, caroline freund 2010, "the anatomy of china's export growth" university of chicago press , pp. 35 - 56

xxix. Ministere de l"industrie, de l"energie et des petites et moyennes entreprises „strategie industrielle national a horizon 2016" 
xxx. Mohamed abdelbassetchemingui and nora ann colton 2015 "foreign direct investment in tunisia: role of the free trade agreement with european union" research in middle east economics, volume 6, 21-41

xxxi. Monirbelloumi , 2014, "the relationship between fdi,trade, and economic growth in tunisia , an application of autoregressive distributed lag model" economic system no38 pp269-289

xxxii. Nadia selmi 2011 thèse "transfert technologique facteur d"integration internationale des pays en developpement : cas de la tunisie » universite de tunis el manar faculte des sciences economiques et de gestion de tunis

xxxiii. Nasfifkiliwahiba ,2014 "impact of foreign direct investment on economic growth in tunisia" academic research international vol. 5(2)

xxxiv. Oecd benchmark definition of foreign direct investment fourth edition 2008

xxxv. Oji-okoroizuchukwu, huang huiping 2011 "an empirical analysis on the contribution of foreign direct investment on nigeria economy" proceedings of the 8th international conference on innovation \& management pp.1173-1178.

xxxvi. Park, w. G. And d. C. Lippoldt (2008), "technology transfer and the economic implications of the strengthening of intellectual property rights in developing countries", oecd trade policy working papers, no. 62

xxxvii. Phillip siegle 2008 "explaining fdi performance of maghreb countries : case of morocco, tunisia and algeria : trade patterns and investment policies" cems master in international management

xxxviii. Richard kneller smarandapantea and richard upward 2009 " which international technology transfer channels are effective in raising firm productivity?"

xxxix. Rosa forte 2013 "multinational firms and host country market structure: a review of empirical literature" fep working paper $n 497$

xl. S. Sardadvar, 2011 "economic growth in the regions of europe", contributions to economics, chapter2, p140

xli. Sazali abdul wahab2012, "defining the concepts of technology and technology transfer: a literature analysis" international business research vol. 5, no. 1

xlii. Stanley fischer 1993 "the role of macroeconomic factors in growth" journal of monetary economics no.32, pp.485512.

xliii. Staskolenikov "estimation and testing with unit roots"

xliv. Sung-cheol lee, kark-bum lee and ji-yeon ryu 2003 "technology transfer of foreign direct investment in china" geography association ,vol. 88, no. 4, pp. 289-299

xlv. Vinish kathuria 2000 "productivity spillovers from technology transfer to indian manufacturing firms" journal of international development (j. Int. Dev) n.12, pp 343-369

xlvi. Wolfgang keller 1997 "trade and the transmission of technology" national bureau of economic research working paper n6113

xlvii. Xiaohui liu and chenggang wang 2003 "does foreign direct investment facilitate technological progress? Evidence fromchinese industries" research policy n32 pp. 945-953

xlviii. Zouhourkarray et sofiane toumi 2007 " investissement direct étranger et attractivité appréciation et enjeux pour la tunisie », revue d'économie régionale \& urbaine, p. 479-501

xlix. Zvigriliches 1998 "interindustry technology flows and productivity growth: a reexamination" the national bureau of economic research (p. 241 - 250) analysis of a potential free trade agreement between the european union and south korea"

1. Gramma corrected by beya chebbi (chebbibeya91@yahoo.com) 


\section{Annexure}

\begin{tabular}{|c|c|c|c|c|c|c|c|c|c|}
\hline \multicolumn{10}{|c|}{ With Constant and Trend (3rd Specification) } \\
\hline \multicolumn{5}{|c|}{ 1st diffrence } & \multicolumn{5}{|c|}{ 2nd diffrence } \\
\hline & \multicolumn{2}{|c|}{ unite root } & \multicolumn{2}{|c|}{ trend } & \multirow[b]{2}{*}{ Variable } & \multicolumn{2}{|c|}{ unite root } & \multicolumn{2}{|c|}{ trend } \\
\hline Variable & $\begin{array}{c}\text { test } \\
\text { statistic }\end{array}$ & $\begin{array}{c}1 \% \\
\text { Critical } \\
\text { value }\end{array}$ & Pvalue & $\begin{array}{c}1 \% \\
\text { Critical } \\
\text { value }\end{array}$ & & $\begin{array}{c}\text { test } \\
\text { statistic }\end{array}$ & $\begin{array}{c}1 \% \\
\text { Critical } \\
\text { value }\end{array}$ & Pvalue & $\begin{array}{c}1 \% \\
\text { Critical } \\
\text { value }\end{array}$ \\
\hline d.GDP & -4.3499 & -4.3943 & 0.0956 & $1 \%$ & & & & & \\
\hline d.FDI & -8.903 & -4.284 & 0.8416 & $1 \%$ & & & & & \\
\hline d.Ses & -4.2311 & -4.284 & 0.2042 & $1 \%$ & d2.Ses & -6.8519 & -4.3098 & 0.6955 & $1 \%$ \\
\hline d.DI & -4.5953 & -4.3743 & 0.1642 & $1 \%$ & & & & & \\
\hline d.X & -5.2629 & -4.2845 & 0.5477 & $1 \%$ & & & & & \\
\hline d.Pl & -6.256 & -4.3098 & 0.4039 & $1 \%$ & & & & & \\
\hline d.M & -6.3428 & -4.2845 & 0.1868 & $1 \%$ & & & & & \\
\hline d.Xma & -7.0609 & -4.2845 & 0.0027 & $1 \%$ & d.2Xma & -6.3229 & -4.3292 & 0.9156 & $1 \%$ \\
\hline d.Mma & -4.247 & -4.3239 & 0.0165 & $1 \%$ & d2.Mma & -4.4816 & -4.356 & 0.8094 & $1 \%$ \\
\hline d.tel & -0.5812 & -4.2845 & 0.0675 & $1 \%$ & d2.tel & -5.8475 & -4.2967 & 0.0761 & $1 \%$ \\
\hline $\begin{array}{l}\text { d.FDI } \\
\text { (EU7) }\end{array}$ & -5.1648 & -4.3239 & 0.9274 & $1 \%$ & & & & & \\
\hline
\end{tabular}

Table 1: ADF test result

Source: Our calculations based on output EVIEWS 9.0

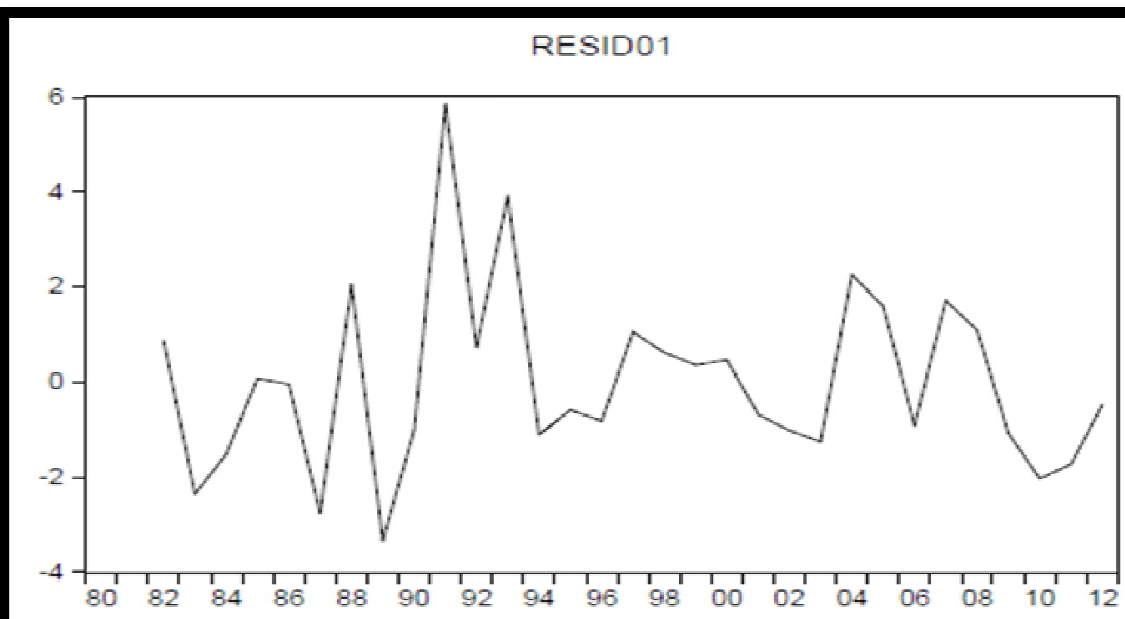

Figure 1: Residual of 1 st Equation

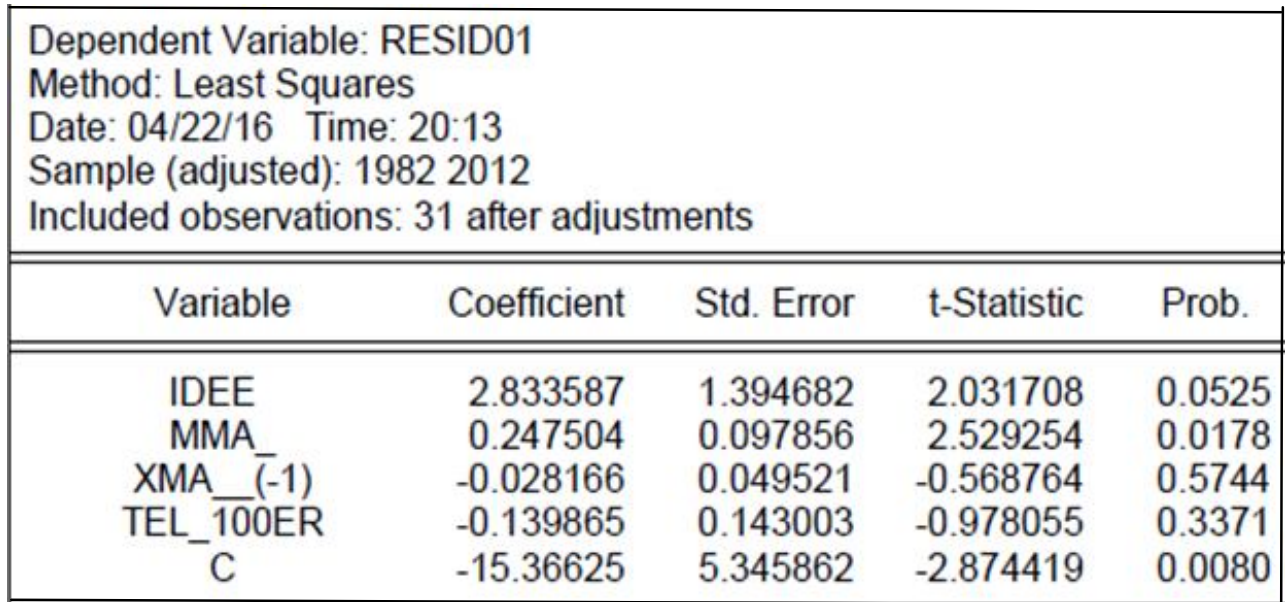

Table 2 